\title{
Ten-minute administration of bevacizumab
}

\author{
Sara García Gil, ${ }^{1}$ Fernando Gutiérrez Nicolás, ${ }^{1}$ Guillermo A González De La Fuente, ${ }^{1}$ \\ Gloria J Nazco Casariego, ${ }^{1}$ M Micaela Viña Romero, ${ }^{2}$ J Norberto Batista López ${ }^{3}$
}

'Department of Pharmacy, University Hospital of Canary Islands, Santa Cruz de Tenerife, Spain

2Department of Pharmacy, University Hospital Nuestra Señora de la Candelaria, Tenerife, Spain ${ }^{3}$ Department of Clinical Oncology, University Hospital of Canary Islands, Tenerife, Spain

Correspondence to Mrs Sara García Gil, Department of Pharmacy, University Hospital of Canary Islands, Carretera Ofra s/n, 38320, San Cristobal de La Laguna, Santa Cruz de Tenerife, Spain; saragg1991@gmail.com

Received 9 February 2017 Revised 21 May 2017 Accepted 5 June 2017 Published Online First 29 June 2017

EAHP Statement 1 : Introductory Statements and Governance

\begin{abstract}
Objective To describe our experience of administering bevacizumab doses at $0.5 \mathrm{mg} / \mathrm{kg} / \mathrm{min}$. The main objective of the study was to evaluate the safety of this regimen of administration. Secondary endpoints were to evaluate the cost saving and satisfaction of patients with the reduction in treatment delivery time.

Methods The study included all patients who received bevacizumab therapy during 18 months. Time savings was calculated comparing time of normal-administration regimen (90-60-30 $\mathrm{min}$ ) versus time with the new administration rate $(0.5 \mathrm{mg} / \mathrm{kg} / \mathrm{min})$. Finally, importance of the reduction in the treatment delivery time for patients was surveyed.

Results A total of 713 infusions (73 patients) were included in the study. Just one grade 1-HSR was observed and no high-grade HSRs occurred during the study period. The new infusion rate saved $14980 \mathrm{~min}$ which means a saving of $€ 26940.30$ ( $€ 17960.20$ per year). A convenience sample of patients ( 25 patients) was interviewed, with an averaged in the importance of time savings by 8.8 points on the visual analogue scale. Conclusions Our results show how this infusion rate of bevacizumab can be administered safely with benefit both for the patients and for the health systems by economic savings.
\end{abstract}

\section{INTRODUCTION}

Monoclonal antibodies with pharmacological activity are increasingly used therapeutic tools in the treatment of oncological processes. ${ }^{1}$ This is due, among other reasons, to their lower toxicity compared with conventional chemotherapy and their action is sometimes limited to the tumour cells. $^{2}$ However, they are large size protein molecules, in many cases of non-human origin, which can cause anaphylactic reactions after administration. ${ }^{3}$ Hence, it is generally recommended that the first dose be infused at a lower rate than the following doses. ${ }^{4}$

Bevacizumab is a monoclonal antibody widely used for its antiangiogenic action, ${ }^{5}{ }^{6}$ whose mechanism of action is based on blocking vascular endothelial growth factor-A. ${ }^{7}$ This is not a fully human monoclonal antibody (containing 10\% murine protein) ${ }^{8}$ and the recommendations are that the first dose should be administered in $90 \mathrm{~min}$, the second in $60 \mathrm{~min}$ and subsequent doses in $30 \mathrm{~min}$, in order to avoid possible infusion-related hypersensitivity reactions (HSRs). However, in a recent analysis of phase I and II trials of bevacizumab, Reidy et $a l^{10}$ found no relationship between HSRs and the rate of administration of bevacizumab, provided it was not higher than $0.5 \mathrm{mg} / \mathrm{kg} / \mathrm{min}$. Based on these findings, the objective of the present work was to describe our experience of administering all doses of bevacizumab at $0.5 \mathrm{mg} / \mathrm{kg} / \mathrm{min}$ to confirm their safety in routine clinical practice at a tertiary hospital. Secondarily, we calculated time and cost savings in a Day Hospital Oncology Unit (DHOU) when using this dosing regimen compared with the standard regimen (initial and escalated administration rates recommended in FDA approved product labelling) and quantified patient evaluation of the reduction in treatment delivery time.

\section{METHODS}

We performed an observational, prospective, single-centre study during 18 months (1 October 2014-1 April 2016). The study included all patients receiving antineoplastic therapy with bevacizumab, for different indications. Computerised pharmacy records were used to identify those receiving bevacizumab during the study period.

Patients were requested to sign an informed consent form prior to the inclusion. Institutional review board approval was not required.

Delivery rates for each of the available doses were $0.5 \mathrm{mg} / \mathrm{kg} / \mathrm{min}$, that is, for a dose of $5 \mathrm{mg} / \mathrm{kg}$ (administration in $10 \mathrm{~min}$ ); $7.5 \mathrm{mg} / \mathrm{kg}$ (in $15 \mathrm{~min}$ ); $10 \mathrm{mg} / \mathrm{kg}$ (in $20 \mathrm{~min}$ ) and $15 \mathrm{mg} / \mathrm{kg}$ (in $30 \mathrm{~min}$ ), all from the first administration.

The time saved was calculated as the difference between recommended initial and escalated administration rates and fixed rate of $0.5 \mathrm{mg} / \mathrm{kg}$ per min. The cost of DHOU stay (€273 per treatment session) was taken from the latest figures published in 'Boletín Oficial de Canarias' (the Official Bulletin of the Canary Islands), 2015. Cost savings were estimated based on the average length of stay of a patient in the DHOU; according to different treatment duration regimens.

Possible HSRs were identified by review of clinical data stored on our hospital computer application SAP. The degree of HSR severity was assessed according to the criteria established by the Common Terminology Criteria for Adverse Events version $4.0 .^{11}$

The time saved with the new regimen per treatment session was $20-80 \mathrm{~min}$, according to individual. The importance for a convenience sample of patients of reducing treatment delivery time was surveyed using the visual analogue scale (VAS), where 0 represented no importance and 10 great importances.

\section{RESULTS}

The study included 73 patients who collectively received a total of 713 infusions of bevacizumab during the study period. 
Table 1 Number of patients and total number of infusions for each infusion rate of bevacizumab at $0.5 \mathrm{mg} / \mathrm{kg} / \mathrm{min}$

\begin{tabular}{ccc}
\hline Infusion rate $(\mathbf{m g} / \mathbf{k g})$ & Number of patients (\%) & $\begin{array}{l}\text { Total number of } \\
\text { infusions (\%) }\end{array}$ \\
\hline 5 & $24(32.9)$ & $221(31.0)$ \\
7.5 & $4(5.5)$ & $43(6.0)$ \\
10 & $36(49.3)$ & $329(46.1)$ \\
15 & $9(12.3)$ & $120(16.8)$ \\
\hline
\end{tabular}

Initial infusion rates of 90 and $60 \mathrm{~min}$ were not used for any of the patients. Twenty-four patients received a dose of $5 \mathrm{mg} /$ $\mathrm{kg}$ (total 221 infusions); four received a dose of $7.5 \mathrm{mg} / \mathrm{kg}$ (43 infusions), 36 received a dose of $10 \mathrm{mg} / \mathrm{kg}$ (329 infusions) and nine patients received a dose of $15 \mathrm{mg} / \mathrm{kg}$ (total of $120 \mathrm{infu}-$ sions) (table 1). The new regimen represented a time saving of 249 hours.

From the results, we estimated that the average length of stay in the HDOU during the study period was 2.53 hours per treatment administered, with a total of 713 infusions. With the conventional regimen that time would have been 2.83 hours. Therefore, the time saved with the new dosing regimen was equivalent to 98.6 stays, which means a potential cost saving of $€ 26940$ during the 18 -month study period, or $€ 17960$ per year.

No high-grade HSRs occurred during the study period. Only one case of mild, transient grade 1 HSR was recorded: the patient described a burning sensation in the throat while receiving a dose of $10 \mathrm{mg} / \mathrm{kg}$ of bevacizumab (infusion over $20 \mathrm{~min}$ ); no medication was required to control the reaction.

We interviewed 25 patients about the importance they attached to a reduction of treatment delivery time, which was an average $8.8(6-10)$ points on the VAS.

\section{DISCUSSION}

Our results are consistent with those described by Diane et al. ${ }^{10}$ We found that bevacizumab can be safely administered at a rate of $0.5 \mathrm{mg} / \mathrm{kg} / \mathrm{min}$ from the first infusion, without any anaphylactic reaction or serious HSR in one and a half years of activity. Unlike these authors, we quantified the effect of this measure, which is easy to apply, on optimising resources in hospital oncology units. The new bevacizumab dosing regimen resulted in a reduction of DHOU use equivalent to 98.6 stays during 18 months (65.7 per year). And the resulting cost saving was estimated at $€ 17960$ per year, it is a theoretical concept on the potential indirect economic cost, based on the cost of HDOU stay. The new infusion rate reduces HDOU stay time, so the unit can be used to treat more patients in the same time period, helping with this to reduce DHOU waiting lists; although this aspect was not quantified in the present study. In addition, reduced treatment delivery time greatly appreciated, as shown in the survey, where the average score was almost 9 out of 10 .

In conclusion, the administration of bevacizumab at the rate of $0.5 \mathrm{mg} / \mathrm{kg} / \mathrm{min}$ resulted in a reduction of DHOU costs, without increasing the incidence of infusion-related reactions. Patient perception of the resulting reduction in treatment delivery time was very positive. It would be interesting to perform this type of study for the rest of monoclonal antibodies and achieve greater reductions in global times of treatment delivery in order to optimise the resources available in such units.

Competing interests None declared.

Patient consent Obtained.

Provenance and peer review Not commissioned; externally peer reviewed.

(c) European Association of Hospital Pharmacists (unless otherwise stated in the text of the article) 2019. All rights reserved. No commercial use is permitted unless otherwise expressly granted.

\section{REFERENCES}

1 Scott AM, Wolchok JD, Old LJ. Antibody therapy of cancer. Nat Rev Cancer 2012;12:278-87

2 Chames P, Van Regenmortel M, Weiss E, et al. Therapeutic antibodies: successes, limitations and hopes for the future. Br J Pharmacol 2009;157:220-33.

3 Descotes J. Immunotoxicity of monoclonal antibodies. MAbs 2009;1:104-11.

4 Vogel WH. Infusion Reactions. Clin J Oncol Nurs 2010;14:E10-E21.

5 Gilbert MR, Dignam JJ, Armstrong TS, et al. A randomized trial of bevacizumab for newly diagnosed glioblastoma. N Engl J Med 2014;370:699-708.

6 Miller K, Wang M, Gralow J, et al. Paclitaxel plus bevacizumab versus paclitaxel alone for metastatic breast cancer. N Engl J Med 2007;357:2666-76.

7 Yang JC, Haworth L, Sherry RM, et al. A randomized trial of bevacizumab, an antivascular endothelial growth factor antibody, for metastatic renal cancer. $N$ Engl J Med 2003;349:427-34.

8 Presta LG, Chen $\mathrm{H}, \mathrm{O}^{\prime} \mathrm{C}$ onnor SJ, et al. Humanization of an anti-vascular endothelial growth factor monoclonal antibody for the therapy of solid tumors and other disorders. Cancer Res 1997;57:4593-9.

9 Genentech, Inc. Avastin (Bevacizumab) FDA Drug Label. 2008 http://www.accessdata. fda.gov/drugsatfda_docs/label/2009/125085s0169lbl.pdf (accessed on 10 June 2011).

10 Reidy DL, Chung KY, Timoney JP, et al. Bevacizumab $5 \mathrm{mg} / \mathrm{kg}$ can be infused safely over 10 minutes. J Clin Oncol 2007;25:2691-5.

11 US Department of Health and Human Services, National Institutes of Health, National Cancer Institute. Common Terminology Criteria for Adverse Events (CTCAE). Version 4.0. 2009. 